\title{
ANALISIS KEKERASAN SIMBOLIK DALAM NOVEL A THOUSAND SPLENDID SUNS KARYA KHALED HOSSEINI (PERSPEKTIF PIERRE BOURDIEU) \\ SYMBOLIC VIOLENCE ANALYSIS IN NOVEL A THOUSAND SPLENDID SUNS BY KHALED HOSSEINI (PIERRE BOURDIEU'S PERSPECTIVE)
}

Naskah masuk: 1 Februari 2020, direview: 21 April 2020, disetujui: 25 April 2021

\author{
Andi Nurul Amaliah \\ amaliahdarwis@gmail.com
}

\begin{abstract}
ABSTRAK
Penelitian ini mengkaji tentang kekerasan simbolik yang dialami oleh para tokoh perempuan dalam novel berjudul A Thousand Splendid Suns karya Khaled Hosseini. Bentuk-bentuk kekerasan simbolik diidentifikasi dan dianalisis oleh perspektif sosiologis Pierre Bourdieu. Bourdieu mengusulkan bahwa bahasa adalah sarana untuk melestarikan dan mentransformasikan kekuatan simbolik. Pelaku memiliki kewenangan untuk menetapkan nilai, norma, dan standar, mendikte, dan mengontrol paradigma pelaku lainnya sehingga pelanggaran yang diterima sebagai tindakan yang wajar dan sah. Hasil penelitian menunjukkan bahwa kekerasan simbolik teridentifikasi dalam keluarga. Tokoh perempuan bernama Mariam ini mengalami pelecehan verbal dari ibunya terkait status dan konsepsi tradisional tentang posisi perempuan dalam budaya. Sementara itu tokoh utama ini juga dipaksa menikah dini. Selain itu, karakter wanita lain, Laila juga menerima secara pasif segala bentuk kekerasan. Kedua perempuan tersebut diperlakukan secara diskriminatif dalam masyarakat dan keluarga.
\end{abstract}

Kata kunci: kekerasan simbolik, Pierre Bourdieu, agen, arena

\begin{abstract}
This research studies about the symbolic violence experienced by the women characters in the novel entitled A Thousand Splendid Suns by Khaled Hosseini. The forms of symbolic violences are identified and analyzed by the sociological perspective of Pierre Bourdieu. Bourdieu proposes that language is the means to perpetuate and to transform the symbolic power. The doer has an authority to establish value, norms, and standards, to dictate, and to control the other agents'paradigm making the violences received as the normal and legitimate actions. The result of this research shows that the symbolic violence is identified in the family. The woman character named Mariam experiencing verbal abuse from her mother regarding the status and the traditional conception of woman's position in the culture. Meanwhile this lead character is also forced to early marriage. In addition, another woman character, Laila is also passively accepted all forms of violences. Both women are treated discriminatively in society and family.
\end{abstract}

Keywords: symbolic violence, Pierre Bourdieu, agents, arena

\section{PENDAHULUAN}

\subsection{Latar Belakang}

Bourdieu (2010: 53-57) merumuskan konsep kekerasan simbolik sebagai bentuk kekuasaan terhadap tubuh secara langsung. Kekuasaan itu berlangsung tanpa kekangan fisik apapun. Kekuasaan ini tidak akan terbentuk tanpa didukung disposisidisposisi kepatuhan yang turut memberi andil dalam produksi dari struktur-struktur objektif. Dengan kata lain, kekuasaan simbolik berhubungan dengan dominasi maskulin dan kepatuhan feminin yang dapat dipahami melalui efek-efek durabel atau disposisi-disposisi spontan yang diberikan oleh tatanan sosial kepada perempuan dan laki-laki. Bourdieu (Haryatmoko, 2010:186) mengemukakan lebih lanjut bahwa kekerasan simbolik adalah sebuah bentuk kekerasan atau tindakan kesewenang- 
wenangan yang terjadi karena penerimaan secara sukarela atau ketidaktahuan pihak yang didominasi. Proses dominasi ini belangsung karena baik yang menguasai dan yang dikuasai menerima dan mengakui prinsip-prinsip simbolis tersebut. Prinsip-prinsip ini dapat berwujud bahasa, cara berpikir, cara kerja, dan cara bertindak. Bentuk-bentuk kekerasan dan dominasi simbolik dapat diidentifikasi dalam lingkungan keluarga

Afganistan dikenal sebagai negara konservatif yang tidak bersahabat bagi kaum wanita. Penilaian ini berdasarkan tingginya tingkat kekerasan yang dialami oleh perempuan dalam keluarga. Perempuan seringkali mengalami intimidasi jika mencoba untuk mengambil peran dalam ranah publik. Akses dan ruang gerak perempuan sangat dibatasi di negeri ini. Hal ini tentu erat terkait dengan budaya masyarakat Afganistan yang tidak mentolerir sikap-sikap perempuan yang melanggar norma-norma budaya atau agama. Berdasarkan polling yang dilakukan oleh TrustLaw, sebuah lembaga yang bergerak dalam menyebarkan berita dan informasi tentang hak-hak perempuan menunjukkan bahwa Afghanistan menempati nilai tertinggi di tiga faktor resiko, yakni antara lain faktor resiko kesehatan, kekerasan non-seksual, dan keterbatasan akses ekonomi (Moore: 2011).

Salah seorang penulis terkenal yang mengangkat kehidupan perempuan Pakistan dalam tulisannya adalah Khaled Hosseini. Dia adalah seorang pria kelahiran Afghanistan yang berprofesi sebagai dokter di Amerika. Novel a Thousand Splendid Suns merupakan novel kedua setelah novel perdananya yang sangat laris yang berjudul The Kite Runner. A Thousand Splendid Suns bertengger selama 15 minggu di daftar New York Times Bestseller. Novel ini terjual lebih dari satu juta kopi diminggu pertama perilisannya. Kesuksesan dari novel ini tidak terlepas dari kepiawaian penulis dalam menuangkan fenomena sentral dan realitas masyarakat Afghanistan ke dalam sebuah karya fiksi. Penulis membawa pembaca untuk ikut merasakan kepedihan atas konflik dan permasalahan yang dialami tokoh-tokoh utama dalam cerita. Novel ini mampu mengaduk emosi pembaca dan menambah wawasan seputar konflik dan peperangan yang terjadi di Afghanistan.

Novel A Thousand Splendid Suns secara garis besar mengisahkan tentang kehidupan dua tokoh utama, yakni Mariam dan Laila. Sejak kecil, Mariam telah menerima kekerasan simbolik dari ibunya. Ibunya senantiasa melontarkan kalimatkalimat bernada sinis yang sarat kebencian terhadap Mariam. Selain itu, Mariam juga mendapatkan perlakuan yang tidak adil dari keluarga ayahnya karena sejarah dan latar belakang Mariam yang merupakan anak hasil hubungan diluar nikah. Bagi masyarakat Afghanistan yang menjunjung nilai-nilai Islam, hubungan diluar pernikahan merupakan pelanggaran besar dan dianggap menodai kehormatan diri dan keluarga. Mariam akhirnya tidak mendapatkan posisi yang baik dan menguntungkan karena lahir dari sebuah hubungan terlarang. Selain itu, tokoh penting kedua yang bernama Laila, juga menerima kekerasan simbolik dalam hubungan rumah tangga yang dijalinnya bersama Mariam dan Rasheed. Dalam kondisi terdesak, ia bersedia menjadi istri kedua Rasheed dan berbagi suami dengan Mariam. Namun, pada akhirnya kedua wanita ini justru disatukan oleh penderitaan yang sama dan rasa saling membutuhkan satu sama lain. Novel ini menggambarkan secara detil kehidupan dua perempuan yang mengalami dominasi simbolik baik yang diterima dari orang tua seperti yang dialami Mariam dan dominasi pria yang diterima oleh tokoh Mariam dan Laila dalam budaya patriarki di Afghanistan.

\subsection{Rumusan Masalah}

Berdasarkan latar belakang yang telah dikemukakan sebelumnya, maka permasalahan dalam tulisan ini adalah bentuk-bentuk kekuasaan simbolik yang 
digambarkan dalam novel A Thousand Splendid Suns karya Khaled Hosseini.

\subsection{Tujuan Penelitian}

Secara khusus, penelitian ini bertujuan untuk memaparkan bentuk-bentuk kekuasaan simbolik yang terdapat dalam novel A Thousand Splendid Suns karya Khaled Hosseini dalam perspektif sosiologi Pierre Bourdieu. Secara teoretis, penelitian ini diharapkan dapat memberikan kontribusi pemikiran dalam ruang lingkup penelitian sosiologi sastra.

\subsection{Kajian Pustaka}

Sejumlah penelitian terhadap karya sastra dengan pendekatan sosiologi Pierre Bourdieu telah dilakukan oleh beberapa peneliti sebelumnya. Syahril (2014) dalam penelitiannya yang berjudul "Arena Produksi Kultural dan Kekerasan Simbolik (Analisis terhadap Novel Banat Al-Riyadh Perspektif Sosiologi Pierre Bourdieu" menganalisis representasi tokoh-tokoh perempuan yang menghadapi problematika budaya. Tokoh-tokoh tersebut merupakan pengejawantahan kondisi sosio-kultural perempuan di Saudi Arabia yang berjuang terhadap norma, tradisi, dan etika di tengah arus modernitas. Pertarungan antara tradisi dan modernitas dikaji menggunakan dua konsep utama Bourdieu, yaitu habitus dan arena. Hasil penelitian ini menunjukkan bahwa kekuasaan simbolik hadir dalam berbagai arena yakni negara, masyarakat patriarki, dan keluarga. Penelitian ini mendudukkan penulis sebagai agen yang menegosiasikan ideologi modernitas di tengah kungkungan tradisi yang berlaku di Arab Saudi.

Penelitian selanjutnya dilakukan oleh Zurmailis dan Faruk (2017) dengan judul "Doksa, Kekerasan Simbolik, dan Habitus yang Ditumpangi dalam Konstuksi Kebudayaan di Dewan Kesenian Jakarta." Penelitian ini mengkaji doksa yang diusung oleh Dewan Kesenian Jakarta dengan pendekatan strukturalisme konstruktivis Pierre Bourdieu. Menggunakan konsep habitus, arena, dan struktur yang dikemukakan oleh Bourdieu, peneliti menyimpulkan bahwa doksa yang dijadikan agen sebagai pedoman dalam tindakannya, dalam hal ini aktivitas seni yang dilakukan berasal dari struktur budaya yang dibangun melalui kekerasan simbolik yang kemudian direproduksi. Ini menunjukkan bahwa struktur dan agen saling mempengaruhi satu sama lainnya.

Selain kedua penelitian yang telah dipaparkan sebelumnya, peneliti lain yang mengkaji novel dengan menggunakan konsep habitus dan modal Bourdieu adalah Ginting (2019). Peneliti memfokuskan kajiannya pada habitus dan modal tokoh-tokoh dalam arena Pendidikan sebagaimana yang tergambarkan dalam novel Sang Pemimpi karya Andrea Hirata. Melalui pendekatan diskursif M.H. Abrams, peneliti menyimpulkan bahwa Ikal dan Jimbron memiliki sejumlah habitus. Ikal, Jimbron, dan Arai disinyalir tidak memiliki modal ekonomi dan simbolik. Akan tetapi, ketiga tokoh tersebut memiliki modal sosial. Dari segi modal budaya, Ikal lebih unggul dibandingkan Arai dan Jimbron. Penelitian ini menunjukkan bahwa habitus seseorang dapat mempengaruhi penguasaan modal tertentu yang kemudian akan menentukan posisinya dalam suatu arena.

Melalui perspektif Bourdieu, Novenia, Taum, Adji (2019) juga menganalisis strategi dominasi dalam novel Maryam karya Okky Madasari. Penelitian ini menunjukkan bahwa terdapat tiga kelas sosial berbeda dalam novel, yaitu kelas dominan, kelas borjuasi baru, dan kelas borjuasi kecil. Sehubungan dengan penguasaan modal, kelompok Ahmadiyah memiliki modal sosial dan simbolik yang lebih besar daripada kelompok Islam yang unggul di modal budaya (agama), dan Ahmadiyah dalam hal ini terdominasi karena dipandang sebagai kelompok yang asing dan menyimpang. Peneliti lebih lanjut juga mengidentifikasi dua arena yakni arena agama dan arena 
ekonomi yang merupakan medan pertarungan para agen berserta modal-modal yang dikuasainya.

Berdasarkan beberapa penelitian yang telah dikemukakan sebelumnya, maka dapat ditarik kesimpulan bahwa penelitian yang memfokuskan kajiannya pada isu kekerasan simbolik yang dialami oleh para tokoh-tokoh yang terdapat dalam novel $A$ Thousand Splendid Suns belum pernah dikaji sebelumnya. Oleh karena itu, penelitian ini bertujuan untuk mengidentifikasi secara lebih komprehensif bentuk-bentuk kekuasaan simbolik dalam arena keluarga dan masyarakarat dengan pendekatan sosiologi Pierre Bourdieu.

\subsection{Landasan Teori}

Dalam lensa pemikiran Pierre Bourdieu, kekerasan simbolik merupakan bentuk -bentuk penguasaan secara simbolik, misalnya kebudayaan terhadap suatu kelompok. Kelompok yang terdominasi tersebut lalu memandangnya sebagai hal yang absah dan lumrah terjadi. Hal ini disebabkan karena legitimasi atau otoritas yang dimiliki oleh pelaku yang pada akhirnya melanggengkan relasi kekuasaan melalui penerimaan dan pengakuan secara sah. Kebudayaan dalam hal ini memperkuat akarnya melalui hubungan kekuasaan tersebut yang kemudian direproduksi melalui tindakan para agen dalam sebuah arena. Dominasi tersebut terbentuk dari proses yang disebut "salah mengenali" atau misrecognition, yaitu sebuah mekanisme relasi kekuasaan yang dipandang secara subjektif dan diterima sebagai hal yang benar di mata pemeluknya.

Symbolic violence yang dalam bahasa Indonesia dikenal sebagai kekerasan simbolik berpusat pada tindakan pedagogis yang dipandang sebagai pemaksaan secara arbitrer suatu nilai dan norma kebudayaan yang terdiri atas tiga bentuk, antara lain; 1) Diffuse education yang artinya pendidikan yang tersebar luas melalui interaksi para agen dalam suatu sistem sosial, 2) Pendidikan dalam ruang lingkup keluarga, 3) Pendidikan Pendidikan formal di instansi sekolah. Agen dalam hal ini memiliki kekuataan simbolik untuk mendidik atau menanamkan makna, nilai, atau standar tertentu dalam sebuah relasi kekuasaan. Tindakan pedagogik ini ditentukan oleh kewenangan atau otoritas pedagogis seorang agen. Kewenangan ini merupakan pola kekuasaan arbitrer yang dijalankan oleh pelaku dan diakui oleh pihak yang dikuasai. Tindakan dalam relasi tersebut diterima sebagai sesuatu yang netral, positif, atau alamiah. Jadi, kekuasaan simbolik tidak hanya terjadi dalam dunia pendidikan, namun juga berlangsung dalam ruang lingkup keluarga. Orang tua seringkali menunjukkan otoritas dan bentuk-bentuk dominasi terhadap anaknya (Jenkins, 2004: 157-159).

Menurut Burdioeu, kekuasaan simbolik bermakna kekuasaan untuk melakukan pengelompokan sosial berdasarkan indikator-indikator tertentu, misalnya jenis kelamin, wilayah, bangsa, ras, etnis, umur, atau status sosial. Pengelompokan tersebut ditunjukkan melalui ujaran verbal yang digunakan untuk merepresentasikan individu, kelompok, atau lembaga tertentu. Selain itu, kekuasaan simbolik dapat pula dimaknai sebagai suatu cara untuk mendikte dan menanamkan sebuah pandangan dan tujuan tertentu ke dalam pikiran orang lain. Bahasa dalam hal ini merupakan sarana kekuasaan simbolik atau dengan kata lain, menjadi alat yang digunakan agen untuk menerapkan otoritas dan kekuasaan penuh yang dimiliki terhadap orang lain (Bourdieu, 2011: 182184).

Bourdieu lebih lanjut mengemukakan bahwa bahasa menjadi bagian integral dalam mengontrol orang lain. Bahasa merupakan pengejawantahan harapan, rencana, dan ambisi seseorang. Bahasa yang digunakan dalam tindak tutur komunikasi seharihari yang digunakan untuk memerintah, menasihati, dan membujuk orang lain dan disisi lain melalui bahasa seseorang mendengarkan, mematuhi, atau mengekspresikan 
diri. Bourdieu memandang kekerasan simbolik sebagai hal sentral dalam bahasa. Dia memandang bahasa bukan hanya sekedar alat komunikasi namun merupakan cara yang digunakan manusia untuk mengontrol satu sama lain (Harker, dkk., 2005: 225).

Kekuasaan simbolik bagi Bourdieu adalah kekuasaan yang disampaikan melalui ujaran atau ungkapan yang membuat orang lain mempercayainya. Kekuasaan untuk mengendalikan atau mengubah pandangan objektif mengenai suatu hal atau bahkan tindakan hal tersebut. Kekuasaan simbolik bahkan memungkinkan seseorang untuk memperoleh hal yang setara diperoleh melalui kekuatan fisik maupun ekonomi. Kekuasaan yang hanya dapat diterapkan melalui misrecognition sebagai sesuatu yang arbitrer. Jadi, kekuasaan simbolik terbentuk melalui hubungan antara orang -orang yang menjalankan kekuasaan dan yang tunduk terhadap kekuasaan tersebut. Terdapat sebuah kepercayaan terhadap keabsahan ujaran dan terhadap orang yang menyampaikannya (Bourdieu, 1991: 170).

Berdasarkan beberapa pengertian kekerasan simbolik yang telah dikemukakan sebelumnya, dapat disimpulkan bahwa kekerasan simbolik adalah suatu bentuk dominasi simbolik dalam sebuah relasi antara agen yang berkuasa dan yang menerima kekuasaan tersebut sebagai sesuatu yang legitimate dan alamiah. Dalam penerapan kuasa simbolik, bahasa merupakan elemen penting sebagai sarana pengontrol tindakan seseorang dalam ranah. Praktek kekuasaan ini dapat terbentuk dari institusi terkecil yakni keluarga dalam hubungan antara orang tua dan anak atau suami dan istri.

Kekerasan simbolik yang terjadi tidak dapat dilepaskan dengan beberapa konsep lain yang dikemukakan oleh Pierre Bourdieu, yakni habitus, ranah, dan modal. Kekerasan simbolik yang dialami oleh seseorang erat kaitannya dengan praktik habitusnya. Habitus adalah sekumpulan disposisi yang kemudian terbentuk melalui struktur objektif maupun sejarah yang dialami oleh individu (Harker, Mahar, dan Wilkas, 2005: 13). Habitus juga dapat berarti sebuah kebiasaan yang terus berulang yang dilakukan oleh seorang individu dalam berbagai hal dalam praktik sosialnya. Habitus seorang agen atau individu juga dipengaruhi oleh tempat atau ranah terjadinya praktik sosial tersebut.

Ranah merupakan wadah ataupun tempat berlangsungnya segala aktifitas individu dalam lingkungan bermasyarakat. Habitus seseorang ternyata dapat menetap maupun berubah-ubah berdasarkan ranah/tempat agen tersebut berada. Ranah juga menjadi sarana seorang agen untuk menunjukkan eksistensi dirinya atau mempertahankan dominasinya dalam suatu lingkungan, sehingga ranah juga dapat disebut sebagai "arena bertarung" agen yang satu dengan yang lainnya untuk mempertahankan dominasinya. Di dalam proses tersebut, kehadiran modal sangat dibutuhkan.

Menurut pandangan Bourdieu, modal harus ada di dalam sebuah ranah/tempat agar ranah/tempat dapat memiliki arti dan fungsi. Modal adalah suatu kemampuan yang dimiliki oleh agen atau seseorang dalam berinterkasi dengan masyarakat lain dalam kehidupan sosialnya. Modal dapat terbentuk berdasarkan habitus yang dimiliki oleh seseorang. Selain itu, kelas seseorang juga dapat ditentukan oleh seberapa banyak modal yang dimiliki oleh individu tersebut., modal terdiri dari beberapa bagian, yakni modal ekonomi, yakni kepemilikan barang seperti alat-alat produksi dan materi, modal budaya (pendidikan dan warisan keluarga), modal sosial yaitu relasi antara agen yang satu dengan agen lainnya dalam suatu kelompok atau komunitas yang berkuasa dalam lingkungan sosial, dan yang terakhir adalah modal simbolik seperti prestise, status, dan otoritas (Adib, 2012, hlm. 107).

\section{METODE PENELITIAN}


Metode yang digunakan dalam penelitian ini adalah metode kualitatif dengan menggunakan novel A Thousand splendid Suns untuk mejawab permasalahan yang ada di dalam teks melalui studi pustaka. Dan pada penelitian ini juga digunakan teori yang dikemukakan oleh Pierre Bourdieu terkait praktik sosial yang dialami oleh tokoh-tokoh di dalam teks terkait habitus, modal, ranah yang menyebabkan terjadinya kekerasan simbolik pada tokoh-tokohnya.

\subsection{Metode Pengumpulan Data}

Dalam penelitian novel A Thousand Splendid Suns, digunakan metode deskriptif kualitatif serta beberapa referensi melalui buku dan artikel terkait permasalahan yang diteliti di dalam novel ini.

Langkah-langkah yang dilakukan adalah:

1. Melakukan pembacaan secara seksama melalui (close reading), kemudian mengumpulkan data dari kutipan-kutipan di dalam teks.

2. Mengelompokkan referensi terkait sebagai penunjang data-data yang akan dianalisis.

3. Menganalisis teks dengan menggunakan teori Pierre Bourdieu dengan konsep praktik sosial (habitus, modal, arena) untuk melihat bagaimana kekerasan simbolik terjadi pada tokoh-tokoh perempuan di dalam lingkungannya.

Menarik kesimpulan dari analisis yang dilakukan.

\subsection{Metode Analisis Data}

Metode analisis data yang digunakan dalam penelitian novel A Thousand Splendid Suns adalah metode deskriptif kualitatif dan metode analisis isi. Deskriptif kualitatif digunakan untuk melihat keselurahan isi yang terdapat di dalam teks terkait tokoh, alur, serta konflik. Analisis ini digunakan untuk meneliti kekerasan simbolik yang dialami oleh tokoh-tokoh perempuan serta pengaruh teori praktik sosial Pierre Bourdieu di dalam lingkungan tokoh-tokoh perempuan tersebut berada.

\section{PEMBAHASAN}

\subsection{Kekuasaan Simbolik Keluarga terhadap Anak}

Keluarga merupakan institusi terkecil dimana bentuk-bentuk kekuasaan simbolik berlangsung. Sebagaimana yang dikemukakan Bourdieu (2010: 49-50) struktur -struktur dominasi merupakan produk dari reproduksi tanpa henti (bersifat historis), dilakukan beberapa agen tunggal (termasuk laki-laki melalui kekerasan simbolik) dan melalui beberapa institusi seperti keluarga, gereja, sekolah, atau negara. Jason Mandryk dalam bukunya yang berjudul Operation World (2010: 166\&170) mengemukakan bahwa sebagai negara yang pernah berada dalam tirani Taliban, Afghanistan saat ini mengalami perbaikan secara progresif namun masih terbilang konservatif dengan perubahan yang tidak begitu signifikan. Akses perempuan dalam ranah publik masih terbatas. Kaum perempuan yang melek huruf kurang dari $20 \%$ dan hanya $5 \%$ yang menempuh pendidikan sekolah menengah. Lebih dari setengah pengantin di Afghanistan berusia dibawah 16 tahun, dan sepertiga dari kaum perempuan pernah mengalami tindak kekerasan. Mempekerjakan dan melibatkan perempuan secara sosial masih menjadi isu sensitif di negara ini. Berdasarkan hal tersebut, bentuk-bentuk kekerasan simbolik yang terjadi dalam keluarga dikemukakan melalui analisis yang dilakukan terhadap novel A Thousand Splendid Suns. Perilaku dan interaksi tokoh-tokoh yang terdapat dalam novel merupakan refleksi dari realitas sosial Afghanistan.

Mariam adalah salah satu karakter utama dalam novel yang senantiasa menerima hujatan dari ibunya. Ibunya yang ia sebut Nana memanggilnya dengan sebutan Harami. Harami merupakan uangkapan bahasa Arab yang jika diterjemahkan 
bermakna anak haram. Julukan tersebut disematkan padanya sejak ia kecil tanpa peduli arti dari kata harami itu sendiri. Hal ini dapat dilihat dari penggalan novel berikut.

"Dasar Harami kecil ceroboh. Inilah ganjaran yang kudapatkan setelah hidup sengsara.

Harami ceroboh kecil yang menghancurkan warisanku” (Hosseini,2008 :20).

Harami bermakna anak yang lahir diluar ikatan pernikahan. Mariam menjadi objek kekesalan ibunya sejak ia lahir. Ibunya tidak segan memakinya dan menyebutnya dengan istilah harami sebagai bentuk penyesalan atas perbuatannya di masa lalu. Mariam hanya menerima segala tindakan dan ujaran-ujaran ibunya dan hanya menganggapnya sebagai ekspresi marah belaka tanpa ingin mencari tahu lebih lanjut makna dari setiap perkataan ibunya. Mariam mulai menyadari maksud dari kata-kata ibunya saat ia telah dewasa dan menerima kenyataan bahwa dirinya memang adalah anak haram yang tidak akan pernah memperoleh hak seperti yang diperoleh orang lain. Perkataan ibunya justru semakin memperkuat pandangannya bahwa ia tidak akan mendapatkan cinta, keluarga, dan penerimaan oleh masyarakat. Bourdieu mengemukakan bahwa dominasi simbolik yang terjalin merupakan relasi kekuasaan yang terbentuk karena adanya penerimaan dari pihak yang terdominasi. Dalam hal ini, anak berada dibawah kontrol atau kekuasaan orang tua sehingga cenderung mengakui dan menerima segala bentuk kekerasan simbolik.

Ibu Mariam adalah seorang pembantu di rumah ayahnya. Saat ketiga istri dan keluarga Jalil, ayah Mariam, mengetahui bahwa Nana (Ibu Maryam) mengandung anak dari hubungan terlarang, ia yang saat itu tengah mengandung Mariam diusir dari rumah tempatnya bekerja. Alih-alih mempertahankan Nana dan Mariam untuk tetap tinggal dirumah itu, Jalil justru menyalahkan dan menuduh Nana yang telah menggoda dan merayunya lebih dulu. Sikap Jalil memperlihatkan bentuk otoritas pria terhadap perempuan yang dengan seenaknya memperlakukan ibu Mariam. Aghanistan menganut sistem budaya patriarki. Sistem ini menghasilkan ketidakadilan, kekerasan, dan penindasan. Dalam sistem ini, laki-laki yang berkuasa untuk menetukan atau membuat keputusan dilandasi oleh pembagian peran berdasarkan seks (Murniati, 2004: 80-81). Sebagai seseorang yang berada di bawah kekuasaan Jalil, ibunya hanya dapat menerima dirinya yang dicampakkan tanpa melakukan perlawanan apapun karena tidak memiliki modal apapun untuk mempertahankan dan membela diri.

Selain mendapatkan julukan yang tidak pantas, Mariam bahkan tidak diperbolehkan oleh ibunya untuk mengecap pendidikan. Ibunya menanamkan pada dirinya bahwa tidak ada gunanya bagi orang seperti mereka untuk bersekolah karena pada akhirnya pendidikan tidak akan mengubah nasib dan pandangan orang lain terhadap mereka. Hal ini dapat dilihat dari kutipan berikut ini.

Apa gunanya menyekolahkan anak perempuan sepertimu? Sama saja dengan memoles peludahan

"hanya ada satu keahlian. Tahamul. Bertahan." (Hosseini, 2008: 42-43).

Mendengar perkataan ibunya, Mariam hanya mengangguk dan mematuhinya. Ia tidak lagi meminta untuk disekolahkan karena telah memahami bahwa ibunya tidak akan membiarkannya untuk sekolah seperti anak-anak lainnya. Ibunya menekankan lagi bahwa sekolah tidak akan membuat dirinya lebih baik. Sikap Mariam menunjukkan bahwa ia membiarkan ibunya untuk mengontrol kehidupannya dan menganggap hal tersebut sebagai sikap yang wajar yang dilakukan oleh orang tua terhadap anaknya.

Perlakuan yang tidak menyenangkan yang dialami oleh Mariam tidak hanya datang dari perlakuan Ibunya, akan tetapi juga dilakukan oleh ketiga istri Jalil. Setelah kematian ibunya, hak asuh Mariam jatuh ke tangan ayahnya yaitu Jalil sehingga, Mariam harus tinggal di kediaman Jalil yang dihuninya bersama isteri-istrinya. Kehadiran 
Mariam di rumah itu membuat ketiga istri Jalil merasa terganggu. Salah satu upaya yang mereka lakukan untuk membuat Maryam dapat keluar dari rumah mereka adalah dengan membiarkan Mariam menikah. Hal ini terlihat melalui kutipan di bawah ini:

Harga diri mereka telah terinjak-injak karena kelahirannya, dan inilah kesempatan terakhir bagi mereka untuk menghapuskan, sekali dan untuk selamanya, jejak terakhir dari skandal memalukan suami mereka. Mariam harus disingkirkan karena dia merupakan perwujudan yang hidup dan bernapas dari aib mereka. (Hosseini, 2008: 53)

Teks di atas memperlihatkan bahwa ketiga istri Jalil menganggap Mariam adalah aib dan merupakan kesalahan besar. Kelahiran Mariam dan kehadirannya di rumah mereka membuat ketiga istri Jalil merasa terganggu dan menganggap bahwa Mariam adalah ancaman besar bagi mereka sehingga ketiga istri Jalil berusaha untuk membuat Maryam keluar dari rumah tersebut. Tindakan yang dilakukan oleh isteriisteri Jalil menunjukkan sebuah tindakan mekanisme dominasi yang terjadi di dalam arena keluarga.

Arena menurut pandangan Bourdieu adalah sebuah "tempat bertarung" para agen untuk merebut maupun mempertahankan posisi mereka dalam suatu tempat. Hal ini terjadi pada ketiga isteri Jalil yang merasa bahwa Mariam adalah saingan terberat mereka dalam ranah/arena keluarga. Kehadiran Mariam yang dianggapnya sebagai hal yang memalukan keluarga juga menjadi alasan mekanisme dominasi itu terjadi agar nama keluarga besar Jalil yang selama ini terpandang dan dihormati oleh banyak orang tetap terjaga.

Selain itu, kekuasaan simbolik juga diperlihatkan oleh ayah Mariam, Jalil, dan ketiga istrinya yang menunjukkan otoritasnya untuk menikahkan Mariam di usia dini saat umurnya masih lima belas tahun. Mariam bahkan tidak diberi pilihan apakah ingin menerima atau menolak keputusan ayahnya. Hal ini dapat dilihat melalui penggalan novel berikut.

Aku pernah melihat gadis sembilan tahun menikah dengan pria yang berumur dua puluh tahun lebih tua daripada jodohmu, Mariam. Kami semua pernah melihat yang seperti itu.

Berapa umurmu? lima belas? Itu usia yang tepat bagi gadis untuk menikah.” (Hosseini, 2008: 86).

Mariam dinikahkan pada usia yang sangat belia dengan seorang lelaki yang usianya jauh lebih tua darinya. Dirinya hanya bisa menerima keputusan tersebut dan menjalani kehidupan rumah tangga dengan seorang pria pilihan ayahnya. Ia bahkan tidak menyadari bahwa ketiga istri ayahnya ingin menyingkirkankanya melalui pernikahan tersebut. Dirinya dianggap sebagai perwujudan skandal memalukan suami mereka dan aib yang harus segera dilenyapkan.

Teks di atas menunjukkan bahwa tokoh Mariam telah mengalami kekerasan simbolik yang dilakukan oleh ketiga istri Jalil dengan mengatakan bahwa suatu kewajaran seorang perempuan menikah di usia yang masih sangat muda. Selain kekerasan simbolik yang dialami oleh Maryam.

\subsection{Kekuasaan Simbolik Patriarki}

Dalam budaya patriarki, laki-laki senantiasa menunjukkan dominasinya dalam hubungan rumah tangga. Patriarki merupakan istilah yang merujuk kepada kekuasaan laki-laki atau suatu sistem dominasi dan superioritas laki-laki, sistem kontrol terhadap perempuan yang berada dalam posisi dikuasai. Dengan kata lain istilah patriarki merujuk kepada kekuatan simbolik yang dijalankan oleh laki-laki (ayah atau suami) di dalam sebuah sistem (Bhasin, 1996:1-4). Lebih lanjut dipaparkan bahwa perbedaan biologis antara perempuan dan laki-laki secara kultural menghasilkan perspektif bahwa perempuan merupakan makhluk yang lemah dan membutuhkan perlindungan. 
Kelemahan inilah yang kemudian dimanfaatkan laki-laki untuk melanggengkan dominasinya (Abdullah, 2001: 50). Dominasi simbolik pria atas wanita juga menjadi isu sentral dalam novel ini. Selama menjalani pernikahan dengan seorang pria pilihan ayahnya yang bernama Rasheed, Mariam juga harus merasakan pahitnya kehidupan yang berada dalam pengawasan penuh suaminya. Hal ini tercermin melalui penggalan novel berikut.

Di tempat asalku, wajah perempuan hanya boleh dilihat oleh suaminya. Aku ingin kau mengingatnya. Paham?

Mariam mengangguk. Dia mengulurkan tangan untuk menerima kantung kertas yang

disodorkan oleh Rasheed (Hosseini, 2008: 117-118).

Rasheed adalah pria konservatif yang mewajibkan Mariam untuk menutupi wajahnya menggunakan burqa atau cadar. Ia memiliki pandangan bahwa seorang wanita yang telah menikah tidak boleh memperlihatkan bagian tubuhnya termasuk wajah kepada pria selain suaminya. Mariam menuruti keinginan suaminya dan menggunakan cadar kemanapun ia pergi. Meskipun pada akhirnya ia mengetahui bahwa suaminya justru tidak melaksanakan hal-hal yang ia katakan dan tidak menjalankan anjuran agama, ia tetap menganggap bahwa perintah suaminya adalah sesuatu yang sah dilakukan sebagai bentuk kasih sayangnya terhadapnya.

Sikap protektif suaminya berlanjut dengan membatasi pergaulan Mariam. Ia tidak diperkenankan untuk bertemu dengan kawan-kawan suaminya dan tidak diperbolehkan untuk menyapa laki-laki lain. Hal ini dapat dilihat melalui kutipan berikut.

Para tamu mendatangi rumah mereka. Semuanya pria, kawan-kawan Rasheed. Ketika ketukan terdengar di pintu, Mariam dengan tahu diri segera pergi ke kamarnya di atas dan menutup pintu. Dia berdiam di sana sementara Rasheed dan para tamunya di bawah, minum teh, merokok, mengobrol. Rasheed memberi tahu Maryam bahwa dia tidak boleh turun hingga semua tamu pergi (Hosseini, 2008: 133).

Mariam tidak merasa keberatan dengan permintaan suaminya yang membatasi ruang pergaulannya. Ia justru merasa tersanjung dan merasa berharga dan dianggap penting sebagai seorang istri. Sikap Mariam yang mengakui tindakan suaminya sebagai sesuatu yang absah dan alamiah merupakan bentuk relasi kekuasaan simbolik yang tercipta antara dirinya dan suaminya. Bourdieu (2010: 48\&55) memaparkan bahwa perempuan melakukan tindakan-tindakan pengakuan terhadap praktik, persetujuan atas doxa dan keyakinan. Meski tidak disukai, tindakan-tindakan itu memperkuat dominasi yang dialami oleh kaum terdominasi karena mereka menerima aturan-aturan yang dipaksakan kepada mereka.

Perlakuan Rasheed yang ditunjukkan kepada isterinya Mariam bukan hanya bentuk dari kuasa simbolik semata. Bentuk kuasa simbolik tersebut juga dipengaruhi oleh habitus yang dimiliki oleh Rasheed dan telah terbentuk dan tertanam sebagai bagian dalam dirinya. Rasheed adalah seorang laki-laki Afghanistan yang hidup dalam lingkungan yang menganut budaya atau pemahaman bahwa isteri-isteri mereka hanya boleh dilihat oleh suami dan mewajibkan perempuan-perempuan yang telah menikah untuk memakai burqa apabila ingin bepergian. Pemahaman tersebut yang pada kemudian dipraktikkan oleh Rasheed dalam interaksinya dengan Mariam isterinya.

Kekerasan simbolik yang dialami oleh Maryam merupakan bagian dari habitusnya di masa lalu yang merupakan akibat dari sistem patriarki. Ibu Maryam (Nana) memiliki masa lalu dan kehidupan di bawah naungan patriarki dan mencoba memberikan pemahaman kepada Maryam bahwa laki-laki memiliki kekuasaan dan 
kekuatan yang tidak dimiliki oleh perempuan. Kekuasaan tersebut menempatkan posisi perempuan di bawah laki-laki yang digambarkan melalui kutipan berikut:

Nana berkata, "Camkan ini sekarang, dan ingatlah terus, anakku: Seperti jarum kompas yang selalu menunjuk ke utara, telunjuk laki-laki juga selalu teracung untuk menuduh perempuan. Selalu. Ingatlah ini, Mariam." (Hosseini, 2008:11).

Berdasarkan teks di atas terlihat bahwa Nana memberikan pemahaman kepada Mariam bahwa posisi mereka yang terlahir sebagai perempuan tidak memiliki kekuatan apapun dibanding laki-laki. Laki-laki cenderung melemparkan kesalahan kepada perempuan karena perempuan dianggap sebagai mahkluk yang lemah seperti yang dialaminya saat Jalil menuduh Nana sebagai penyebab dari kesalahan yang dilakukannya.

Habitus inilah yang kemudian melekat pada tokoh Mariam hingga dirinya menikah dengan Rasheed. Kehidupan pernikahan Mariam dan Rasheed tidak berjalan dengan mulus terlebih saat Mariam harus kehilangan janin dalam kandungannya akibat keguguran. Kejadian tersebut membuat perubahan pada perlakuan Rasheed terhadap Mariam. Rasheed melimpahkan kesalahan kepada Mariam atas kegugurannya dan bersikap kasar kepadanya seperti yang terlihat pada kutipan teks di bawah ini:

Tidak mudah bagi Mariam untuk bertoleransi pada sikap Rasheed kepadanya, menahan bentakannya, ejekannya, caranya berjalan melewatinya seolah-olah Mariam hanyalah sekadar kucing peliharaan. Tetapi, setelah empat tahun pernikahan mereka, Mariam melihat dengan jelas betapa besarnya toleransi seorang wanita yang sedang ketakutan. Dan, Mariam memang ketakutan. Sepanjang hari, dia merasa takut pada sikap Rasheed yang berubah-ubah, temperamennya yang mudah marah, kekeraskepalaannya dalam setiap pembicaraan, sehingga kadang-kadang, hanya dipicu oleh perselisihan kecil, dia tidak segan-segan memukul, menampar, atau menendang Mariam. Kadang-kadang dia akan meminta maaf, dan kadangkadang tidak (103)

Selama bertahun-tahun, Mariam telah belajar menguatkan diri untuk menahan penindasan dan penghinaan Rasheed, cemoohan dan kemarahannya. Tapi, rasa takut ini tidak bisa dikendalikannya. Meskipun telah bertahun-tahun hidup bersama Rasheed, Mariam tetap gemetar ketakutan ketika suaminya seperti ini, menyeringai, menggenggam sabuk di kepalan tangannya, menatapnya dengan mata merah nyalang. Mariam ketakutan bagaikan seekor kambing yang dimasukkan ke dalam kerangkeng harimau, ketika sang harimau mengangkat cakarnya dan mulai menggeram. (Hosseini, 2008: 246-247)

Teks di atas memperlihatkan bahwa Mariam tumbuh dan berkembang pada habitus lamanya meskipun telah berada pada lingkungan yang baru. Sama seperti yang dialami oleh ibunya, Mariam tidak memiliki modal yang cukup untuk dapat melawan dominasi kekuasaan yang dilakukan oleh suaminya Rasheed dalam ranah keluarga. Mariam hidup dalam tekanan baik secara batin maupun secara fisik. Penggalan kutipan kalimat Mariam ketakutan bagaikan seekor kambing yang dimasukkan ke dalam kerangkeng harimau semakin mempertegas posisi Mariam dalam sistem patriarki dan semakin mengukuhkan posisi Rasheed yang lebih dominan.

Selain itu, Laila yang merupakan istri kedua Rasheed juga menerima perlakuan yang sama seperti Mariam. Laila adalah seorang perempuan yang hidup dan lahir dari keluarga yang jauh berbeda dengan Mariam. Mariam sejak kecil mengalami keterbatasan dan ruang gerak yang ditimbulkan oleh orang-orang di sekitarnya, sehingga sosok Mariam tumbuh menjadi perempuan yang tidak dapat bersuara atau mengutarakan pendapatnya atas apa yang terjadi pada dirinya. Selain itu, akibat pengaruh habitusnya membuat Mariam tidak memiliki modal atau kelebihan apapun 
sehingga Mariam menggantungkan hidupnya pada sosok lain, dalam hal ini merujuk pada suaminya yang bernama Rasheed. Hal tersebut terlihat berbeda dengan kehidupan istri kedua Rasheed bernama Laila. Seperti yang terlihat pada kutipan berikut:

Laila tahu pasti bahwa dia tidak membutuhkan nasihat ini karena Babi tidak berniat menjodohkan dirinya dalam waktu dekat. Meskipun Babi bekerja di Silo, sebuah pabrik roti besar di Kabul, membanting tulang di tengah panasnya suhu dan dengungan mesin, mengisi oven dan menggiling gandum sepanjang hari, dia adalah seorang sarjana. Dia pernah menjadi guru SMA sebelum komunis memecatnya, tak lama setelah kudeta 1978, sekitar satu setengah tahun sebelum Soviet menduduki Afghanistan. Babi telah memastikan kepada Laila sejak dahulu bahwa hal terpenting dalam kehidupan ini, setelah keselamatan, adalah pendidikan (Hoesseini, 2008: 118).

Berdasarkan kutipan teks di atas, terlihat bahwa Laila adalah sosok perempuan yang hidup dalam lingkungan keluarga yang menganggap bahwa pendidikan bagi perempuan sangatlah penting, meskipun kehidupan perempuan Afghanistan yang telah beranjak remaja di lingkungannya banyak yang dinikahkan oleh keluarga mereka melalui perjodohan. Melalui ranah/arena keluarga dan habitusnya membuat Laila memiliki kemampuan atau modal dalam dirinya yakni, modal budaya yang didapatkanya melalui pendidikan dan warisan budaya yang dalam hal ini didapatkannya dari pemikiran-pemikiran dari ayahnya.

Jika Mariam memiliki habitus yang tertanam dalam dirinya bahwa perempuan tidak harus bersekolah dan berpendidikan, sejak kecil Laila telah ditanamkan sebuah prinsip hidup dari ayahnya yang bernama Babi. Laila tumbuh menjadi perempuan yang cerdas dan mengenyam pendidikan dan memiliki impian masa depan seperti yang terlihat dari kutipan kalimat berikut:

Aku tahu bahwa kau masih muda, tapi aku ingin kau memahami dan mempelajari hal ini sekarang, katanya. Pernikahan dapat menunggu, tapi pendidikan tidak. Kau gadis yang amat sangat pintar. Ini bukan omong kosong. Kau bisa menjadi apa pun yang kau inginkan, Laila. Aku tahu itu. Dan, aku juga tahu bahwa setelah perang ini usai, Afghanistan akan membutuhkanmu, sama seperti ia membutuhkan para pria, bahkan mungkin wanita akan lebih dicari. Karena masyarakat tidak memiliki kesempatan untuk maju jika para wanitanya tidak berpendidikan, Laila. Tidak ada kesempatan (Hosseini, 2008: 118).

Modal budaya seperti pendidikan yang diperoleh oleh Laila membuatnya memiliki harapan serta cita-cita yang besar bagi dirinya dimasa depan seperti yang ditanamakan oleh ayahnya. Ayah Laila berpendapat bahwa pada akhirnya di masa depan perempuan dan laki-laki memiliki hak yang sama dalam segala bidang yang semakin membuat Laila bersemangat untuk menempuh pendidikannya. Namun, hal lain terjadi ketika tokoh Laila berada pada ranah/tempat yang berbeda. Seperti yang dialaminya saat Laila telah menjadi isteri kedua dari Rasheed. Laila mendapatkan kekerasan simbolik dari suaminya seperi yang terjadi pada Mariam dan tidak dapat menggunakan modal yang dimilikinya yang disebabkan oleh dominasi kekuasaan yang dimiliki oleh Rasheed pada ranah keluarga.

Tokoh Laila juga diwajibkan untuk mengenakan burqa dan tidak dibiarkan untuk keluar rumah tanpa Rasheed. Namun, Laila juga menganggap tindakan Rasheed tersebut sebagai bentuk perhatian dan perlindungan suami terhadap istri. Laila menemukan kenyamanan dengan menggunakan cadar saat keluar rumah. Di samping itu, Rasheed menganalogikan Laila dan Mariam seperti properti atau barang kepemilikan. Hal ini dapat dilihat melalui kutipan berikut.

Dia orang yang kuat, pekerja keras, dan tak pernah bersikap sok penting. Bisa dikatakan begini: seandainya dia mobil, dia adalah sebuah Volga. 
"Kamu”, kata Rasheed kepada gadis itu, "kamu sebaliknya" adalah sebuah Benz. Sebuah Benz baru berkelas unggul oh pasti kau pikir aku gila, diwana, karena mengocehkan mobil seperti ini. Aku tidak menganggap kalian mobil. Aku cuma mengumpamakan." (Hosseini,2008: 335).

Dengan nada bercanda, Rasheed mengumpamakan Mariam istri pertamanya seperti mobil Volga dan Laila istri barunya seperti sebuah mobil Benz baru yang lebih berkelas dan unggul dari Vodka. Hal ini menunjukkan bahwa Rasheed tidak menghargai dan menjunjung martabat istrinya. Namun, justru memperlakukan mereka layaknya properti yang dimiliki dan dikontrol penuh. Sikap Rasheed ini menunjukkan dominasi yang dimiliki Rasheed sebagai kepala rumah tangga yang memiliki kekuasaan untuk mengarahkan dan memerintah istrinya. Septiawan dan Sugihastuti (2007: 50) memaparkan bahwa dalam sebuah kebudayaan, serangkaian oposisi terbentuk yang memandang bahwa laki-laki merupakan makhluk yang kuat, agresif, rasional, kompetitif, atau pekerja. Sebaliknya, perempuan dipandang sebagai lemah, pasif, emosional, irrasional, lembut, dan kooperatif cenderung menempatkan perempuan pada posisi yang tidak menguntungkan.

Istri kedua Rasheed, Laila, juga menerima kekuasaan simbolik seperti yang diterima oleh Mariam. Rasheed menegaskan bahwa sebagai suami, ia wajib untuk menjaga kehormatan isterinya dengan menerapkan aturan-aturan ketat yang berhubungan dengan busana dan pergaulan Laila. Ini berkorelasi terhadap apa yang dikemukakan Bourdieu (2010: 52) yakni posisi dominan harus dimiliki laki-laki untuk memperoleh kehormatan yang diakui perempuan apriori, dan diinginkan agar diakui secara universal. Namun, posisi dominan tersebut juga diterima perempuan untuk menjunjung kehormatan mereka sendiri. Wanita menerima relasi hierarki yang terbentuk dan cenderung mencintai sikap dominan pria. Hal ini dapat dilihat melalui penggalan novel berikut.

"Yang kuinginkan sebagai balasan, yah hanya sebuah hal sederhana. Aku memintamu untuk tidak meninggalkan rumah ini tanpa kutemani. Itu saja. Sederhana, bukan? (Hosseini, 2008: 336).

Aku juga memintamu, Jika kita pergi bersama nanti, untuk mengenakan burqa. Sebenarnya ini untuk perlindunganmu sendiri. Inilah yang terbaik. Ada banyak pria gila di kota ini sekarang. Laki-laki yang tidak segan-segan melecehkan isteri orang (Hosseini, 2008: 337).

Kutipan tersebut menunjukkan bahwa dalam menerapkan sebuah dominasi simbolik, Rasheed menempuh cara-cara yang tidak terdeteksi sebagai sebuah bentuk penguasaan terhadap tubuh. Ia memberikan alasan-alasan logis dan menunjukkan sebuah bentuk tanggung jawab suami terhadap isteri. Pujian dan hadiah bahkan turut menyukseskan pola-pola kekuasaan yang berlangsung sebagai ganjaran kepatuhan istri terhadap segala ketentuan yang diberlakukan suami. Laila tentu saja menerima hal ini sebagai suatu hal yang absah dan wajar sehingga tunduk dan bersedia melaksanakan seluruh perintah Rasheed, suaminya.

Kekerasan simbolik yang dialami oleh seseorang erat kaitannya dengan tempat/ ranah berlangsungnya praktik sosial. Selain itu, faktor lain yang menyebabkan kekerasan simbolik terjadi pada seseorang atau dalam istilah Bourdieu disebut agen adalah adanya tindakan mekanisme dominasi yang dilakukan oleh agen lain dalam mempertahankan posisinya. Seperti yang dialami oleh tokoh Jalil. Jalil adalah ayah dari tokoh perempuan yang bernama Mariam. Di mata Nana, ibu dari Mariam, Jalil adalah sosok laki-laki yang dianggap tidak bertanggung jawab terhadap dirinya dan juga Mariam karena mencampakkan mereka dan mengusir mereka dari rumahnya sehingga, muncullah rasa kebencian di hati Nana terhadap sosok Jalil. Berbeda dengan Nana, di 
mata Mariam, Jalil adalah sosok Ayah yang sangat baik dan perhatian terhadap dirinya. Hal ini terlihat melalui kutipan di bawah ini:

Jalil tidak pernah menyebut Mariam dengan istilah itu. Menurut Jalil, Mariam adalah bunga mungilnya. Dia suka mendudukkan Mariam di pangkuannya dan menceritakan banyak kisah untuknya (Hosseini, 2008: 08).

Berdasarkan kutipan di atas, terlihat bahwa Jalil dalam ranah keluarga telah melakukan sebuah tindakan mekanisme dominasi untuk mempertahankan posisinya. Mekanisme itu terjadi karena sosok Jalil mencoba menciptakan kesan di mata Mariam bahwa dia adalah sosok ayah yang baik dan penyayang meskipun dia adalah laki-laki yang menghamili ibunya sehingga dia terlahir sebagai anak haram atau dalam istilah lain disebut harami yang membuatnya mendapatkan perlakuan yang tidak menyenangkan. Hal tersebut semakin terbukti dengan sikap Mariam yang tetap membela dan menganggap Jalil adalah sosok ayah yang baik yang terlihat dalam kutipan berikut:

Mariam akan mendengarkan kata-kata ibunya dengan patuh. Dia tidak pernah berani mengatakan kepada ibunya betapa dia membenci cara Nana membicarakan Jalil. Kenyataannya, jika berada di dekat Jalil, Mariam sama sekali tidak merasa seperti seorang harami. Setiap Kamis, selama satu atau dua jam, ketika Jalil mengunjunginya, tersenyum lebar dan membawa banyak oleh-oleh, Mariam merasa layak mendapatkan segala macam keindahan dan penghargaan dalam kehidupan. Dan, karena itulah, Mariam mencintai Jalil (Hosseini, 2008: 09).

"Rumput liar," kata Nana. Sesuatu untuk dicabut dan dibuang. Di dalam hati, Mariam mengerutkan kening. Jalil tidak memperlakukannya seperti rumput liar. Dia tidak pernah berbuat seperti itu. Tetapi, menurut Mariam lebih bijaksana jika dia menahan protesnya (Hosseini, 2008:12).

Kutipan di atas memperlihatkan bahwa Mariam telah mendapatkan kekerasan simbolik ketika dia menganggap dirinya sebagai seorang anak yang disayangi oleh ayahnya, di sisi lain, justru mengalami perlakuan yang tidak menyenangkan dari Jalil karena tidak menganggap Mariam dan ibunya sebagai bagian dari keluarga yang sesungguhnya. Mengusir Mariam dan Ibunya dan mengasingkan mereka ke tempat lain yang kondisinya jauh berbeda dengan kehidupan Jalil dan keluarganya di rumah mewah miliknya. Selain itu, dibalik kekerasan simbolik yang dialami oleh Maryim, terjadi sebuah mekanisme dominasi yang dilakukan oleh sosok Jalil agar terlihat sebagai lakilaki dan ayah yang baik dan penyayang di mata Mariam. Jalil seolah tidak ingin dianggap sebagai seorang laki-laki dan Ayah yang jahat sehingga melakukan berbagai tindakan yang dapat membuatnya dirinya terlihat bijaksana.

Seperti yang telah dijelaskan sebelumnya bahwa Afghanistan adalah salah satu negara yang menjadikan patriarki sebagai bagian dari prinsip kehidupan masyarakatnya. Terlahir sebagai perempuan, membuat mereka harus mengikuti segala aturan yang telah terbentuk dari kehidupan sejarah masyarakat Afghanistan. Salah satunya hal yang harus dimiliki oleh perempuan dalam dunia patriarki adalah keharusan perempuan untuk berada di dapur dan mengurus rumah tangga. Perempuan masih memiliki hak dan berkesempatan untuk mengenyam pendidikan di bangku sekolah namun, sebagaian besar dari perempuan Afghanistan masih menganut paham bahwa terlahir sebagai seorang perempuan tidak mewajibkan mereka untuk bersekolah tinggi, tetapi menguasai keahlian di dapur.

Di dalam teks, tokoh Mariam yang begitu bersemangat untuk menempuh pendidikan di bangku sekolah mendapatkan penolakan dari Nana, ibunya. Nana terlihat tidak menyukai keinginan putrinya tersebut, bahkan Nana mencoba memberikan pemahaman kepada Mariam bahwa tugas mereka sebagai perempuan 
adalah berdiam diri di rumah dan melakukan segala pekerjaan rumah tangga. Nana juga menganggap bahwa dengan bersekolah tidak akan membuat perempuan terlihat hebat, tetapi perempuan akan dinilai dari keteladanan mereka dalam mengurus pekerjaan rumah. Hal ini terlihat melalui kutipan teks berikut:

"Apa gunanya menyekolahkan seorang anak perempuan sepertimu? Sama saja dengan memoles peludahan. Tidak ada ilmu yang bisa kau pelajari di sekolah. Yang ada hanya satu, hanya ada satu keahlian yang harus dikuasai perempuan seperti kita dalam kehidupan ini, dan itu tidak diajarkan di sekolah. Lihatlah aku." (Hosseini, 2008: 22).

Teks di atas menunjukkan bahwa patriarki masih melekat kuat sebagai bagian dari kehidupan perempuan-perempuan Afghanistan. Pemikiran semacam ini merupakan sebuah pemahaman yang tertanam di pikiran sebagian perempuan bahwa kewajiban utama mereka adalah mengurus segala hal yang berhubungan dengan rumah tangga. Pemikiran Nana menunjukkan bahwa dirinya sebagai perempuan telah mengalami kekerasan simbolik yang berlaku dalam lingkungan sejarah masyarakat tempat dirinya berada bahwa perempuan tempatnya adalah di rumah. Sikap yang ditunjukkan oleh Nana terhadap keinginan Mariam bukan hanya karena faktor harami yang melekat pada diri Mariam yang membuatnya dipandang rendah oleh orang-orang. Akan tetapi, merupakan bagian dari kekerasan simbolik yang didapatkan oleh Nana dari habitusnya.

Nana terlahir sebagai perempuan yang hidup di dalam keluarga yang memiliki kehidupan sosial dan ekonomi yang rendah. Habitus Nana yang didapatkannya berasal dari pemikiran-pemikiran kehidupan masa lalu atau sejarah masyarakat terkait kehidupan yang harus dijalani sebagai seorang perempuan khususnya perempuan yang terlahir dari keluarga kelas bawah. Selain itu, Nana juga menghabiskan kesehariannya sebagai pembantu rumah tangga sehingga memengaruhi cara Nana dalam berpikir dan bertindak. Sikap Nana memperlihatkan bahwa kekerasan simbolik maupun patriarki tercipta berkaitan erat dengan habitus dan ranah atau tempat proses berlangsungnya tindakan-tindakan tersebut. Dalam pandangan Bourdieu, habitus yang tercipta pada diri seorang individu atau agen bisa berubah maupun menetap. Berdasarkan sikap yang diperlihatkan Nana membuktikan bahwa Nana masih hidup dalam habitus lamanya yakni, cara dia memandang kehidupan sebagai seorang perempuan yang mengutamakan keahlian dapur dan mngurus rumah tangga dan mencoba menanamkan hal tersebut pada putrinya, Mariam.

Sistem patriarki yang membentuk habitus tokoh Nana (Ibu dari Mariam) juga terlihat ketika dia marah dan mencoba memberikan pemahaman kepada Maryam saat dirinya diusir keluar dari kediaman Jalil dan menegaskan bahwa seorang perempuan sepertinya merupakan perempuan penggoda dan tidak bernilai sedikitpun. Seperti yang terlihat melalui kutipan teks di bawah ini:

"Kau tahu apa yang dia katakan kepada istri-istrinya untuk membela diri? Bahwa aku mendesakkan diri padanya. Bahwa semua itu salahku. Didi? Kau lihat? Begitulah arti perempuan di dunia ini." (Hosseini, 2008:11)

Teks di atas menunjukkan adanya sikap diskriminasi terhadap kaum perempuan yang digambarkan melalui tokoh Nana. Diskriminasi terjadi karena memiliki kaitan dengan sistem patriarki dalam masyarakat pada ranah/tempat berlangsungnya praktik sosial tersebut. Selain dianggap sebagai kaum yang lemah, perempuan juga memiliki stigma negatif dalam pandangan masyarakat seperti perempuan yang lahir dari keluarga kelas bawah dianggap sebagai perempuan penggoda laki-laki khususnya laki-laki yang 
memiliki banyak kekayaan. Selain itu, tokoh Nana juga memperlihatkan bahwa perempuan dianggap memiliki moral yang buruk seperti pada penggalan kutipan Bahwa aku mendesakkan diri padanya. Bahwa semua itu salahku.

Stigma negatif terhadap perempuan dalam lingkungan patriarki semakin dipertegas dengan penggalam kalimat Begitulah arti perempuan di dunia ini. Selain penggambaran negatif terhadap kaum perempuan, teks di atas juga menunjukkan adanya sikap berkuasa atau dominasi yang dilakukan oleh Jalil yang semakin menggambarkan betapa kuatnya sistem patriarki saat Jalil melakukan pembelaan di hadapan istri-istrinya bahwa bukan dirinya yang harus disalahkan atas kejadian tersebut. Habitus yang terbentuk pada tokoh Nana membuat dirinya terus memandang rendah dirinya sebagai kaum perempuan dan menganggap perempuan tidak memiliki kuasa seperti yang dimiliki oleh laki-laki. Penyebab habitus Nana dalam bersikap juga dipengaruhi oleh tidak adanya modal yang dimilikinya dalam lingkungan tempatnya berada.

Habitus Nana yang diperlihatkannya pada Maryam yang dipengaruhi oleh masa lalu dan kehidupan Nana sejak dulu juga digambarkan melalui tokoh Mullah Faizullah yang sudah mengenal Nana sangat lama. Mullah Faizullah mengetahui kehidupan dan keseharian Nana yang pada akhirnya membentuk pemikiran maupun perilakunya yang ditunjukkan melalui kutipan berikut:

"Kau tahu, aku telah mengenal ibumu sejak kau belum ada, ketika dia masih menjadi seorang gadis kecil, dan aku bisa mengatakan kepadamu bahwa ketika itu pun dia sudah tidak bahagia. Bibit dari apa yang dia lakukan sekarang telah tertanam sejak lama.

Maksudku adalah ini bukan salahmu. Ini bukan salahmu, Anakku." (Hosseini, 2008: 49).

Seperti yang telah dijelaskan sebelumnya, habitus erat kaitannya dengan modal yang harus dimiliki oleh agen dalam beinteraksi dengan agen lainnya dalam suatu ranah tertentu. Tokoh Nana tidak memiliki modal atau kemampuan yang cukup untuk bersuara dan membela diri dihadapan Jalil dan istri-istrinya sehingga dalam ranah tersebut Jalil dapat dengan mudah menguasai dan mendominasi dan membuat Nana yang hanya merupakan pembantu rumah tangga yang terlahir dari kelas sosial bawah tidak dapat melakukan aksi atau tindakan untuk melakukan pembelaan.

\section{PENUTUP}

Analisis bentuk-bentuk kekuasaan simbolik terhadap novel A Thousand Splendid Suns menunjukkan bahwa keluarga merupakan lembaga dimana kekerasan simbolik mulai terbentuk. Dalam keluarga, orang tua memiliki peranan dan andil yang besar dalam menjaga keteraturan dan melestarikan tradisi dan budaya yang telah dipegang teguh. Namun seringkali orang tua menerapkan pola-pola kekuasaan yang justru bersifat memojokkan dan merugikan anak. Ibu Mariam dalam novel melontarkan ungkapan bernada sinis yang sarat akan penghinaan kepada anaknya karena tidak mampu menerima kenyataan di masa lalunya bahwa hubungan intim di luar pernikahan merupakan hal yang tabu dan terlarang dalam sistem budaya yang menjunjung tinggi nilai-nilai islam seperti Afghanistan. Nana, Ibu Mariam merasa memiliki otoritas terhadap anaknya sehingga dengan seenaknya melayangkan ujaran verbal bernada kasar bahkan menolak untuk menyekolahkan anaknya yang tentu berhubungan dengan budaya Afghanistan yang akses perempuan ke ranah publik sangat dibatasi dan adanya ideologi bahwa kekuasaan perempuan terbatas di arena domestik. Mariam akhirnya tumbuh menjadi seorang perempuan yang rendah diri dan cenderung pasif terhadap setiap perlakuan bahkan penindasan yang diterimanya. Ia membiarkan dirinya berada di 
bawah kontrol orang lain termasuk saat ayahnya memutuskan untuk menikahkannya di usia masih sangat belia. Tidak ada pilihan lain yang dimiliki olehnya selain menerima kenyataan bahwa dirinya memang layak untuk didominasi. Selain itu, kekuasaan juga ditunjukkan tokoh Rasheed sebagai suami terhadap kedua isterinya.

Sebagai negara yang menjunjung tinggi budaya patriarki, laki-laki Afghanistan berada di posisi yang menguntungkan karena ia memiliki kontrol penuh terhadap istrinya baik dalam hal busana, cara bersikap, dan ruang lingkup pergaulan. Konstruksi budaya ini menghasilkan sikap pasif, tunduk, dan patuh perempuan terhadap segala aturan dan ketentuan yang berlaku dalam sebuah rumah tangga. Berbagai tindakan yang dilakukan oleh tokoh-tokoh dalam novel A Thousand Splendid Suns juga berkaitan erat dengan faktor habitus mereka masing-masing. Nana dan Mariam yang tumbuh dengan lingkungan patriarki yang kuat serta pemberian pemahaman yang kurang tepat dari Nana kepada Mariam terkait kodrat dan posisi mereka dalam ranah keluarga dan lingkungan tempat mereka berada membuat keduanya tidak memiliki modal yang cukup untuk melakukan perlawanan atas dominasi kekuasaan yang mereka alami. Selanjutnya, Jalil dan Rasheed yang terlahir sebagai laki-laki dalam budaya patriarki masyarakat Afghanistan semakin mengukuhkan posisi mereka. Selain itu, dengan kepemilikan berbagai modal seperti modal ekonomi, modal budaya hingga modal simbolis yang semakin memperkuat posisi Jalil dan Rasheed untuk melakukan mekanisme dominasi. Terakhir adalah posisi Laila, Laila tumbuh dengan modal budaya yang didapatkannya melalui jalur pendidikan dan memiliki habitus yang berbeda dengan Nana dan Mariam. Laila berada pada ranah keluarga yang memberikan dukungan terhadap posisinya sebagai perempuan. Namun, ketika Laila berpindah ranah yang lain, dalam hal ini adalah ranah keluarga saat Laila menjadi istri kedua Rasheed, Laila justru turut mendapatkan kekerasan simbolik seperti yang dialami oleh Mariam. Sistem patriarki dan dominasi kuasa Rasheed pada ranah keluarga serta kepemilikan modal yang lebih banyak membuat Laila tidak dapat menggunakan modal yang dimilikinya untuk melakukan perlawanan. Pada akhirnya Laila bernasib sama dengan Mariam yang tunduk pada aturan patriarki.

\section{DAFTAR PUSTAKA}

Abdullah, Irwan. 2001. Seks, Gender, dan Reproduksi Kekuasaan. Yogyakarta: Tarawang Press.

Adib, Mohammad. 2012. Agen dan Struktur dalam Pandangan Pierre Bourdieu. Jurnal BioKultur, Vol. I, NO. 2, Desember, 2012.

Bhasin, Kamla. 1996. Menggugat Patriarki. Yogyakarta: Bentang.

Bourdieu, Pierre. 1991. Language and Symbolic Power. Cambridge: Polity Press. . 2010. Dominasi Maskulin. Yogyakarta: Jalasutra. . 2011. Choses Dites Uraian \& Pemikiran Pierre Bourdieu. Bantul: Kreasi Wacana.

Ginting, Harpindo Syah Putra Hilarion. 2019. 'Novel Sang Pemimpi Karya Andrea Hirata: Analisis Habitus dan Modal dalam Arena Pendidikan menurut Perspektif Pierre Bourdieu." Jurnal Ilmiah Kebudayaan SINTESIS Vol. 13, No.1, Maret 2019.

Harker, Richard, dkk., 2005. (Habitus $x$ Modal) + Ranah = Praktik Pengantar Paling Komprehensif kepada Pemikiran Pierre Bourdieu. Yogyakarta: Jalasutra.

Haryatmoko, 2010. Dominasi Penuh Muslihat Akar Kekerasan dan Diskriminasi. Jakarta: Gramedia Pustaka Utama.

Hosseini, Khaled. 2008. A Thousand Splendid Suns. Bandung: Qanita. Jenkins, Richard. 2004. Membaca Pikiran Bourdieu. Bantul: Kreasi Wacana. Mandryk, Jason. 2013. Operation World.Yogyakarta: Yayasan Gloria. 
Muniarti, A. Nunuk P. 2004. Getar Gender. Magelang: IndonesiaTera.

Moore, Charlie. 2011, Poverty, non-existent healthcare and relentless tribal violence: Why Afghanistan is the worst country in the world for women, http:// www.dailymail.co.uk/news/article-2003926/Afghanistan-worst-country-worldwomen.html diakses tanggal 10 November 2016 pukul 20.00 WIB.

Novenia, Maria, dkk. 2019. "Strategi Dominasi dalam Novel Maryam Karya Okky Madasari: Perspektif Pierre Bourdieu." Jurnal Kebudayaan SINTESIS Vol. 13, No.2, Oktober 2019.

Saptiawan, Itsna Hadi dan Sugihastuti, 2007. Gender dan Inferioritas Perempuan: Praktik Kritik Sastra Feminis. Yogyakarta: Pustaka Pelajar.

Syahril. 2014. "Arena Produksi Kultural dan Kekerasan Simbolik (Analisis Terhadap Novel Banat Al-Riyadh Perspektif Sosiologi Pierre Bourdieu)." Jurnal Ilmiah Peuradeu: Media Kajian Ilmu Sosial, Politik, Hukum, Agama, dan Budaya Vol II, No. 01, Januari 2014.

Zumarlis dan Faruk. 2017. "Doksa, kekerasan Simbolik, dan Habitus Uang Ditumpangi dalam Konstruksi Kebudayaan di Dewan Kesenian Jakarta.” Adabiyyat: Jurnal Bahasa dan SastraVol. I, No.1, Juni 2017. 